\title{
Lecky's circle: thoughts from the frontier of international
} law I

\author{
by James Bacchus
}

The author, Chairman of the Appellate Body of the World Trade Organization, reflects in a two part article on what the nineteenth century moral philosopher W E H Lecky can tell us about our own era.

$\Lambda$ s every Londoner knows, Samuel Johnson once said that, "When a man is tired of London, he is tired of life" (James Boswell, Life of Johnson (Oxford: Oxford University Press, 1980), 859 [1791]). I never tire of London, because London is so full of life. No doubt my wife, Rebecca, would add that it is true also that I never tire of London because London is also full of books. When in London, I spend much of my time looking at old books on the dusty shelves of London's bookshops. Sometimes, Rebecca even lets me buy one.

In truth, I must confess that I spend much of my life looking at old books on dusty shelves in bookshops all over the world. One of my favorites is "The Bookworm," a small bookshop on the Rue Sismondi in Geneva that specializes in used English books. I can often be found in "The Bookworm" on those weekends in Geneva when I am not too busy reading the fine print of voluminous WTO panel reports.

It was there where I first met a Londoner named William Edward Hartpole Lecky. It happened some time ago on a rainy Sunday afternoon in "The Bookworm." On several previous visits, my eye had been caught by the intriguing title of an old book on the top shelf in the musty section of the bookshop devoted to old tomes on "philosophy." The title on the faded cover of the book was History of European Morals from Augustus to Charlemagne. The author was someone named W E H Lecky. Typical benighted American that I am, I had, at the time, never heard, or read a word, of W E H Lecky.

On my previous visits, my interest in the history of European morals had not proven to be sufficient to overcome the fact that the top shelf in "The Bookworm" is too high for someone of my short stature to reach. But, at last, on this particular rainy Sunday afternoon, my curiosity got the best of me, and I reached up as high as I could, pulled down the old book, and purchased it for the sum of 25 Swiss francs.
It was money well spent. I began reading the book that Sunday evening, read it through most of that night, and finished reading it the next day. Lecky's book on the history of European morals during European antiquity was one I needed to read. In my view the History of European Morals from Augustus to Charlemagne (New York: George Braziller, 1955) Volumes I and II [1869] - hereinafter Morals - is one we all need to read. For, in my view, William Edward Hartpole Lecky was a man who knew the way forward to a morality that can embrace and serve all humanity.

There was a time when W E H Lecky was renowned throughout much of the world. He was once widely seen as a man who had much to say that was worth saying, and worth remembering, about morality and about humanity. When he died, a statue of him was placed outside the University of Dublin in Ireland. Today, that statue still stands there, but, today, the man himself is not much remembered. The lofty reputation that Lecky enjoyed a century ago has for some reason diminished with the passing of the years. Most of his many books are long out of print. They sit unread on dusty shelves in the quiet libraries and in the antiquarian bookshops of the world.

This is unfortunate, for Lecky was a writer and a thinker who was in many ways far ahead of his time. Indeed, he was a writer and a thinker who was in many ways far ahead of our time.

Born in Dublin in 1838, W E H Lecky was a man of many parts. He was an historian. He was an essayist. He was, for a time, a Member of Parliament. He was a wealthy, landed Anglo-Irish aristocrat whose life spanned the Victorian era, and reflected much about that time. He was - in the great tradition of Gibbon, Macaulay, Carlyle, Grote, Burke, and others - one of the last of the classic eighteenth and nineteenth century "men of letters" who wrote about history in an elegant and philosophical style that enriched the English language. He has been described 
by his biographer, Donal McCartney, as "one of the last of the great line of amateur literary historians writing in English," and as "one of the last of the historiographical school of the Enlightenment." Many of the personal and anecdotal details about Lecky in this essay are drawn from the excellent biography by Donal McCartney, W E H Lecky: Historian and Politician, 1838-1903 (Dublin, Ireland: The Lilliput Press, 1994). This quotation is on page 189.

After completing his studies at Trinity College, Dublin, Lecky spent several years in additional self-schooling while touring Europe in search of enlightenment. He traveled widely, reading extensively and intensively in all the great continental libraries, and living what he described as a "half vagabond, half bookworm existence, diving into half the libraries of Europe and breaking unhappy porters' backs with the boxes of books (see McCartney, Lecky, at 29)." More than once, his studious travels took him through Geneva. Had "The Bookworm" been there at the time, no doubt Lecky would have found it.

Eventually, Lecky and his boxes of books settled in London. Like many others before and since, he wanted to be near the Reading Room of the British Museum. (His books are on display there today, behind protective panes of glass.) He filled the library in his townhouse in South Kensington with an ever-growing collection of books. He then devoted the rest of his life and his leisure to writing lengthy and thoughtful books in which he tried to solve the persistent puzzle of human progress.

\section{NOTION OF "HUMANITY"}

One of those books is the one that I pulled from the top shelf in "The Bookworm." Written while Lecky was still in his twenties, and first published in 1869 when he was only 31 , it is an account in more than eight hundred pages of the progressive unfolding in antiquity of the notion that there is such a thing as "humanity." Lecky's message in the book resonated in a mid-Victorian world that believed in the progress of humanity. The book went through 15 editions in Great Britain. It was even more popular at the time in the United States. Dusty though the book may be, its message resonates even today. For, even today, we are far from understanding, and even farther from implementing, Lecky's moral message for all humanity.

Lecky's message was about a circle. Here (from Morals, vol II, at 256) is some of what he had to say:

"In the first dawning of the human intelligence ... the notion of duty, as distinguished from that of interest, appears, and the mind, in reviewing the various emotions by which it is influenced, recognises the unselfish and benevolent motives as essentially and generically superior to the selfish and the cruel. But it is the general condition of society alone that determines the standard of benevolence $a$ the classes toward which every good man will exercise it. At first, the range of duty is the family, the tribe, the state, the confederation. Within these limits every man feels himself under moral obligations to those about him; but he regards the outer world as we regard wild animals, as beings upon whom he may justifiably prey."

Elsewhere in the same book (vol I, at 100-01), Lecky elaborated on this provocative thought:

"Men come into the world with their benevolent affections very inferior in power to their selfish ones, and the function of morals is to invert this order. The extinction of all selfish feeling is impossible for an individual, and if it were general, it would result in the dissolution of society. The question of morals must always be a question of proportion or of degree. At one time the benevolent affections embrace merely the family, soon the circle expanding includes first a class, then a nation, then a coalition of nations, then all humanity, and finally, its influence is felt in the dealings of man with the animal world..."

Lecky described this expanding circle of human morality (Morals, vol I, at 285) as "the enlarging circle of sympathy." This circle of sympathy that he saw unfolding progressively in human history, and that he foresaw as eventually including all of humanity, might be described as Lecky's circle.

W E H Lecky was an old-fashioned moral philosopher. His idea was that ever-higher, ever-broader moral standards of the duties we owe to one another as human beings evolve as signs of an ever-unfolding, ever-advancing progress in human history. His idea was that history records and reflects an ever-evolving, ever-progressing, ever-expanding human morality. His was a simple idea, and the way he chose to express his idea was with the simplicity of the circle. We live our lives in circles, and the size of our circles shapes the dimensions of our lives. The larger our circle, the larger our lives, for the larger our circle, the larger our scope of concern for others, and the larger our claim to the morality of a true humanity.

I have a front row seat on the frontier of international law. For this reason, I was asked to speak in London about my view of the many far-flung frontiers of international law. The contemplation of those frontiers causes me to linger with Lecky's thoughts about circles. I do so because, as I see it, the true frontiers of international law are not the frontiers of law at all. They are the frontiers of the human morality that precedes law. They are the frontiers of our range of duty to the rest of humanity. In my judgment, in my experience, in my view from the circle where I live on the frontier of international law, the boundaries of the circle of our human sympathy are the true frontiers. For they are the frontiers that ultimately define also the boundaries of what we truly recognize and respect as law, and, therefore, of what we truly are willing to uphold and enforce as law.

Lecky has long since left us. He died 100 years ago, in 1903, while, fittingly enough, reading one of the books in his London library. Lecky is gone. But, a century later, the 
frontiers of international law are expanding in ways that he foresaw. They are expanding because the circle of human sympathy is expanding. The significance of international law is increasing in the world because of the ongoing enlargement in the world of what we see as our range of duty. Today, a century after Lecky's death, the boundaries of international law are at last approaching the visionary boundaries of Lecky's circle.

This can be seen in many of the frontiers of international law. However, perhaps most clearly, perhaps most visibly, and perhaps most significantly, this can be seen in the frontier of international law where I live and where I have spent the past eight years. It can be seen where I spend much of my time when I am not browsing in old bookshops. It can be seen in the frontier of international law called the "WTO."

The "WTO" is, of course, the World Trade Organization. There may be no more important, no more innovative, and no more controversial international institution in all the world than the World Trade Organization. The WTO is less than a decade old, but has been busy from its very beginning expanding the range of human duty, extending the frontiers of international law, and thereby contributing to the enlargement of the human circle.

There are many examples of how busy we are at the WTO. One is the rising pile of WTO dispute settlement reports on my desk that prevents me from spending more of my time reading the thoughts of W E H Lecky. But just how busy we are at the WTO is perhaps best illustrated by the ever-increasing numbers of people going online all around the world to learn more about the WTO. The number of people who visit "wto.org” monthly has now reached twenty-two million, and is rising rapidly. There are no dusty shelves on the WTO website.

If he is among the growing millions who are surfing the WTO website, if he is somewhere today in some wired celestial library sifting through the thousands of pages of reports of WTO proceedings that have been placed on the Worldwide Web, then surely Lecky is smiling at the success thus far of the WTO. The WTO is a conscious and considered international effort to use trade as a means of approaching Lecky's circle. By expanding trade, the WTO is also expanding the opportunities for enlarging the range of human sympathy to include the full extent of Lecky's circle.

\section{WTO APPELLATE BODY}

There are several circles within the WTO that serve an enlarged circle of human sympathy. I would like to think that Lecky is smiling most of all at the accomplishments of the small but busy circle where I live and work within the WTO called the "Appellate Body." The Appellate Body is the circle of seven international jurists who help the nations that are the members of the WTO make binding judgments in final appeals in their international trade disputes.

Our small circle helps the members of the WTO resolve international disputes involving the whole vast and varied array of goods and services that are traded in the world every day - including everything from apples to bananas, from airplanes to poultry, and from shrimp to semiconductors to supercomputers to steel. These international disputes affect billions of people by affecting billions of dollars in world trade. These international disputes result in rulings in international law that affect almost all of world trade.

Ours is a circle of seven that sits at a round table in a small room in the far corner of the far wing of the Italianate villa on the lake of Geneva that serves as the international headquarters of the WTO. As we sit together in our small room, as we work together day by day, our circle seems small to us. But our circle in our small room is large enough to affect almost all the world. Our "range of duty" to the members of the WTO, and, through them, to humanity, includes much of what happens every day in the world economy.

Ours is a circle that is new to the world. Like the WTO itself, the Appellate Body is less than a decade old. The Appellate Body was created along with the WTO as a "quasi-judicial" institution within the WTO in 1995. The WTO is the successor to an earlier international institution, the General Agreement on Tariffs and Trade the "GATT." In a sense that Lecky would surely understand, we are heirs on the Appellate Body to the nearly 50 years of ever-evolving, ever-progressing experience of the GATT in resolving international trade disputes following the end of the Second World War. Like human morality, human political economy, from the GATT to the WTO, is ever-unfolding.

Ours is also a circle that has been drawn by the world. The seven of us who sit around our table were each nominated by our individual countries, but we were each appointed by all of the 146 countries and other customs territories that are members of the WTO. Thus, we each serve all 146 members of the WTO. The members of the WTO account for more than 95 per cent of all world trade by more than five billion people. Every country of the world is either a member of the WTO or seems to want to be. The ever-enlarging circle of WTO membership is expanding rapidly. In time, it will include all the world.

Ours, furthermore, is a circle that has been drawn in the mutual interest of the world. The members of the WTO have invented the WTO-based world trading system as a way of coming together and working together to lower the barriers to trade and, thus, to raise the levels of their mutual prosperity. They have invented the WTO dispute settlement system as a way of upholding the trading rules on which they have all agreed. They have invented the small circle of the Appellate Body as a way of helping them clarify 
their obligations under those rules so they can uphold them within the ever-enlarging circle of the world trading system.

Moreover, ours is a circle of mutual interest that also has been, from the very beginning, a circle of mutual trust. The table of the Appellate Body is round because we seven sit at our table as equals. No one sits at the "head" of our table. Thus, our table is like Thomas Jefferson's table in Monticello long ago. Jefferson believed that those who sit together around a round table sit together as equals, and so do we. We are equal at our table, and we are equal in our trust of one another.

Our mutual trust is the result of our years of hard work while sitting together around our table. The seven of us on the Appellate Body are very different people. We come from seven different backgrounds, seven different cultures, seven different ways of seeing the world. Importantly for our work together around our table, we also come from seven different systems of jurisprudence. But we share one guiding philosophical approach that shapes our perspective and, therefore, shapes as well the results of our work. If Lecky sat with us at our table, undoubtedly he would also share this one guiding approach.

Our work is legal work. Our task is to help the members of the WTO resolve the legal issues that are raised on appeal in WTO dispute settlement. These legal issues are legal questions about the nature of the obligations of the WTO members in the many "covered agreements" of the WTO treaty. Our challenge is thus a legal challenge of working together to reach a consensus on the right legal answers to those legal questions. In this way, we help the members of the WTO clarify those obligations and thus help them resolve difficult international trade disputes.

We have been able to find the right answers through the years at our table in large part because our shared approach to finding the right answers is founded on our firm mutual belief in both the necessity and the value of the conversations that comprise our deliberations. Our deliberations are conversations in the best and truest sense of the word. They are open. They are lively. They are engaging. They are, above all, demanding exercises in mutual criticism. They are extended exercises in advocating, in debating, in communicating, and - most of all - in listening. They are shared efforts in mutual thinking that lead to mutual agreement. They are enlightening conversations that have led the seven of us to our enduring mutual trust.

The seven of us on the Appellate Body may be very different in very many ways. We are very much alike, though, in our mutual confidence in real and reasoned conversation as the right approach to reaching the right answers and to creating mutual trust. This shared confidence has made all the difference to us through the years in building a new institution for the benefit of a world that is much in need of mutual trust.

\section{ENLARGING THE CIRCLE}

On the Appellate Body, we believe that a willingness to engage in reasoned and reasonable deliberation through the principled practice of mutual criticism is one of the keys to creating and sustaining human freedom. We also believe that one of the best ways to enlarge the circle of human sympathy is by enlarging the circle of our thinking through the considerable power of mutual, rational thought. We believe that, by listening to one another, we can learn from one another, and we can learn also to trust one another. We believe, too, that trust sought and secured in this way can serve the cause of human freedom.

This is our shared view. This was, of course, also the view of that other Londoner, Lecky's fellow traveler on the long road to human morality, John Stuart Mill. Perhaps the best statement of Mill's view is in his classic essay On Liberty (London: Penguin Books, 1985) [1859]). No doubt this essay had a place of honor in Lecky's library, as it does in the personal libraries of everyone who has ever served on the Appellate Body. Everyone who has sat at the round table of the Appellate Body would agree that Mill's famous essay expresses abiding truths about how best to serve the cause of human freedom. Indeed, my dear friend and former colleague on the Appellate Body, the late Chris Beeby, of New Zealand, was able to quote long passages of On Liberty from memory.

We may have seven different perspectives on the Appellate Body. We may have seven different points of view on any given legal issue. However, we share with Mill a fundamental belief in reason and in reasonableness. We share with Mill the view that the best way to reach a consensus is the "salutary effect" of a "collision of opinions." We agree with him that "truth has no chance but in proportion as every side of it, every opinion which embodies any fraction of the truth, not only finds advocates, but is listened to." This, as we see it, is the key to securing and serving freedom. And this, as I see it, is the key also to our continuing mutual trust, and to our continuing consensus on the Appellate Body.

The small circle of the Appellate Body serves the large circle of humanity that is represented by the members of the WTO. Our "range of duty" is to the entire population of all of the 146 members of the WTO. Five billion people are with us whenever we sit together at our table. They are all part of our circle of human sympathy. Their needs, their longing, their passions, their aspirations for a fuller and truer humanity - their fondest hopes for freedom - are all ever with us as we reason together in our efforts to help the members of the WTO clarify and uphold their international treaty obligations. We believe that, by reasoning together, we can best serve all their hopes for freedom.

Through our reliance on reasonableness, the mutual criticism around our table creates mutual trust, and the conversation around our table creates consensus. The 
strength of our consensus is reflected in the results of our work thus far. Since the Appellate Body was established in 1995, there have been nearly 60 appeals in WTO dispute settlement. In not one of those appeals has any member of the Appellate Body ever dissented from the findings or the conclusions of any Appellate Body report. Every single one of our decisions has been by consensus. We do not claim infallibility for the Appellate Body, but, to the extent that we seven have been fallible in our work for the members of the WTO, even our most vocal critics must acknowledge that we have been fallible together

To my mind, the consensus we have shared on the Appellate Body has contributed much to the success of our new institution in the short time we have sat together at our table. Claus-Dieter Ehlermann, who sat beside me at our table during my first six years on the Appellate Body, has said that our shared goal from the very start was the establishment of an independent, quasi-judicial institution that would serve all the members of the WTO equally and effectively (see Claus-Dieter Ehlermann, "Reflections on the Appellate Body of the WTO," Address to the American Society of International Law, Washington DC, 3 April 2003).

As usual, I agree with Claus. This has been our mutual goal from the very first time we sat down together, and I would submit that, thus far, we have succeeded in our mutual efforts to achieve it.

There are other reasons as well for our initial success. Contributing also to the success of the Appellate Body in achieving our shared goal of serving the members of the WTO equally and effectively has been our uniqueness as an international tribunal. The Appellate Body is unique in two ways: we have what we lawyers call "compulsory jurisdiction," and we make decisions that are upheld. This is true of no other international tribunal in the world. Indeed, this has never been true of any other international tribunal in the history of the world.

We have compulsory jurisdiction because all of the members of the WTO have agreed in the WTO treaty to use the WTO dispute settlement system to resolve all their treaty-related disputes with other WTO members. We make decisions that are upheld because all of the members of the WTO have agreed in the treaty that any member that chooses - in an exercise of its sovereignty - not to comply with a decision in dispute settlement can be subject to economic sanctions by other members. These potential sanctions can include the loss of some of the valuable trade concessions that have been made by other members in the treaty.

Our uniqueness helps explain why there is no dust on the shelves of the WTO website. Because WTO members must take their treaty-related trade disputes with other WTO members to the WTO, and because the decisions made about those disputes in dispute settlement are upheld, WTO rules and rulings have real force as real international law for the international economy. This means that what happens in the WTO is vitally important to all those five billion people who are served by the WTO and who, as we see it, are always with us whenever we sit down together at our table.

Although our uniqueness is the source of much of our success, it is the source also of much of the controversy that surrounds our rulings. The protests. The press conferences. The speeches in the Congress. The college students in their colourful turtle costumes. None of it would have happened if the Appellate Body were just like every other international tribunal. It is easy to ignore an international tribunal when the authority behind its rulings exists only on paper. It is hard to ignore an international tribunal with compulsory jurisdiction whose decisions are upheld.

Institutionally, our small circle of seven serves a larger circle of the WTO. The reports and recommendations of the Appellate Body are adopted by consensus of another, larger circle within the WTO called the Dispute Settlement Body (DSB). The DSB consists of all 146 WTO members acting together in WTO dispute settlement. The WTO is truly a "member-driven" institution, and the members of the DSB are truly the ultimate decision-makers in WTO dispute settlement.

The DSB is merely the name the members of the WTO use when they are dealing with dispute settlement. The very same countries and other customs territories that comprise the DSB also comprise the largest circle of the WTO, which is the deliberative circle consisting of all of the members of the WTO when they engage in negotiations on new rules for the world trading system. Even now, the members of the WTO are engaged in a new global "round" of multilateral trade negotiations under the auspices of the WTO.

\section{"DOHA DEVELOPMENT ROUND"}

This new round of global trade negotiations is called the "Doha Development Round." Begun in Doha, Qatar, in 2001 , it is the ninth such round of multilateral trade negotiations since the Second World War, and the first since the creation of the WTO. The stakes have never been higher for the world. Goods. Services. Agriculture. Manufacturing. Additional market access of all kinds. The continued lowering of tariff and other trade barriers of all kinds. The negotiation of new rules for competition, investment, intellectual property, and many other areas of the international economy that affect, and are affected by, international trade. These are only a few issues on the agenda of the Doha Development Round. In particular, the overriding goal of the new round is to bring the developing countries of the world into the mainstream of the WTObased world trading system so that they will be able to profit and prosper as they should through expanded opportunities for international trade. 
In a truly "Lecky-like" way, the eight previous global rounds of multilateral trade negotiations have contributed to enlarging the global circle by expanding global economic growth significantly in the past half century. Since the creation of the GATT in the aftermath of the Bretton Woods conference at the conclusion of the Second World War, the GATT-based and, now, WTO-based, world trading system has gradually lowered barriers to trade throughout the world while it has also gradually grown to include almost all of the world. Due in large part to these multilateral efforts, global trade has increased fourteen-fold in the half century or so since the creation of the GATT. This increase in world trade has supported a six-fold increase in global GDP (see World Trade Organization, The Multilateral Trading System: 50 Years of Achievement (Geneva, 1998).

WTO figures show that worldwide exports that, in 1950, accounted for only eight percent of worldwide production, today account for more than 26 per cent of worldwide production. As world trade continues to grow, this percentage continues to grow as well.

Overall, more economic progress has been made in the past half century than in the previous half millennium. Our progress in trade is the most significant economic progress the world has made in the past half century. And much of this progress has been made because of the world trading system that was established under the GATT and is served now by the WTO. Thanks in no small part to trade liberalization, millions upon millions of people in every part of the world have been lifted out of poverty. The dynamic growth of world trade has been the engine of the longest and strongest period of sustained economic growth in human history. Humanity has enjoyed unprecedented prosperity in the wake of what one of Lecky's many intellectual heirs, President John F Kennedy, an early and ardent champion of the multilateral trading system, described rightly - and memorably - as "the rising tide of trade" in a presidential address in Frankfurt, Germany, on 24 June 1963.

The benefits for the United States and for other developed countries from the successful conclusion of the current round of multilateral trade negotiations could be equally significant to this rising tide. The developed countries that are members of the WTO stand to benefit enormously from continued multilateral trade liberalization. One recent study, at the University of Michigan, has concluded that if all the global barriers to trade in goods and services were eliminated, then the gain for the United States alone would be $\$ 537$ billion - almost 6 per cent of the annual US gross domestic product. (The details of the University of Michigan study are discussed in Douglas A. Irwin, Free Trade Under Fire (Princeton: Princeton University Press, 2002), 29-35).

The benefits for the developing countries that are members of the WTO would, however, be even greater. The scheduled implementation of the remaining trade concessions made in the Uruguay Round is expected to facilitate economic growth that will lift an additional 600 million people worldwide out of poverty. We could add impressively to these numbers with the successful conclusion of the current round.

The World Bank has estimated that the abolition of all trade barriers in the new round, coupled with needed market reforms, would add $\$ 2.8$ billion dollars to global income by 2015. Most of this additional global income 1.5 trillion dollars - would be in developing countries. This would lift an additional 320 million people in developing countries out of poverty (see Mike Moore, Director-General of the WTO, "WTO Doha and Beyond: A Roadmap for successfully concluding the Doha Development Round," Address to the Evian VII Plenary Meeting, Montreux, Switzerland (12 April 2002). The elimination of all tariff and non-tariff trade barriers could result in gains for developing countries of $\$ 182$ billion in services, $\$ 162$ billion in manufactures, and $\$ 32$ billion in agriculture.

Not even Lecky would be optimistic enough to suggest that the members of the WTO will abolish all the remaining barriers to world trade in this latest round of negotiations. Trade liberalization has always been an incremental process. Surely it will remain so. Still, these numbers show that abolishing even some of these remaining trade barriers could result in significant benefits for the developing countries that comprise an increasing majority of the membership of the WTO.

In an address to the World Bank in Washington DC in May 2001, President George W Bush said: "We have the opportunity to include all the world's poor in an expanding circle of development." On this, I agree with the President of the United States. Perhaps he, too, has read what W E H Lecky wrote all those years ago about circles. And, in my view, there is no better way to expand the circle of development, there is no better way to further the continued development of developing countries, than through further, mutual, and substantial trade liberalization by the members of the WTO in the Doha Development Round.

Developing and developed countries alike can benefit enormously from the increased economic growth that will result from additional trade liberalization. Everyone everywhere can benefit from more market access in every part of the world. As it is, the global economy is stalled by all the uncertainties occasioned by a unique combination of disease, terror, and economic downturn. I know of no better or surer way to help jump-start the weakened battery of our sluggish global economy than by the negotiation of new rules to lower the remaining barriers to trade in an early, successful, and balanced conclusion to the Doha Development Round.

The benefits of a successful conclusion of the current round would come none too soon for all of us. This would 
be especially so, though, for developing countries. In its Human development report, published in 2001, the World Bank reports that there are 1.2 billion people in the world who live on less than $\$ 1$ per day, and that there are 2.8 billion people in the world who live on less than $\$ 2$ per day. It says that:

"Of the 4.6 billion people in developing countries, more than 850 million are illiterate, nearly a billion lack access to improved water resources, and 2.4 billion lack access to basic sanitation. Nearly 325 million boys and girls are out of school. And 11 million children under age five die each year from preventable causes - equivalent to more than 30,000 a day."

So says the World Bank. These, to say the least, are numbing statistics, and are only a few of those I might have cited; the World Bank's annual reports on "human development" are always well worth reading in their entirety.

We must not, however, be numbed by these statistics. Those of us who see the circle of human sympathy as including all of humanity must not turn our eyes away from these many global human concerns. Lecky was able to live a life of financial ease and lettered leisure because he was an absentee Irish landlord. By all accounts, he was an enlightened landlord. All the same, he was able to spend his time reading in his library and writing his books because he profited from the sweat of others. He never forgot this. Neither must we. To be sure, most of us profit from our own efforts. Yet, most of us also, like Lecky, profit from the sweat of others. And, like Lecky, we must not forget this. One of the best ways we can remember others, one of the best ways we can help others, is through further trade liberalization in a successful conclusion of the Doha Development Round. Significantly, this is also one of the best ways we can help ourselves - because this also happens to be very much in our own self-interest.

Moreover, serious negotiations on a successful conclusion of the current round of multilateral trade negotiations are all the more imperative as a way of reassuring the world at this critical time that the nations of the world do remain capable of cooperating to address their many mutual concerns. At a time when so many of our important international institutions seem at a standstill, at a time when so many of them seem to be in a stalemate, at a time when continued support for so much of what the nations of the world have tried to accomplish together through multilateral efforts and through multilateral institutions seems so very doubtful, the WTO simply must remain a source of stability for the world.

\section{ACHIEVEMENTS THROUGH "MULTILATERALISM"}

The World Trade Organization is an example of all that can be achieved through "multilateralism" to approach Lecky's circle. The WTO is an example of the mutual international trust that can be achieved through consent, through consensus, and, above all, though cooperation. Whatever may happen outside the WTO, the members of the WTO must continue to cooperate within the WTO. They must do so for the sake of all they hope to accomplish together both within and also outside the WTO and also outside the WTO.

This is especially so for the two leading traders in the world - the United States of America and the European Union. Because they are the two leading traders in the world, America and Europe share a special responsibility to cooperate in moving the world forward on trade. If America and Europe can work together for trade, then perhaps they will also be able to work together against terror and for much else that is needed by the world. America and Europe can do much more together to help enlarge the circle of human sympathy than either can do on its own.

In an article entitled "It's multilateralism that makes the world go round" published in the International Herald Tribune on 10 April 2003, The Secretary-General of the International Chamber of Commerce, Maria Livanos Cattaui, advises us that:
"There can be no fortress America, no fortress Europe, in a world in which the fortunes of nations are more tightly intermeshed than ever before. ... The WTO is a shining example of multilateralism at work. Member governments accept its authority as the maker and enforcer of the rules of international trade. The WTO has always managed to overcome conflicts among its members and its authority remains intact. Helping to steer the Doha round to success would be the most dramatic proof the European Union and the United States could offer that the spirit of multilateral cooperation is still alive and well."

With this, too, I agree. In particular, as an American, I think it appropriate that America fulfill its responsibility as the world's leading trading nation by leading in the effort to forge more multilateral cooperation. The United States of America accounts for about twenty percent of all the world's trade. Since 1995, the United States has accounted for about two-thirds of all the world's economic growth (see The Economist, 12 April 2003, 6). America, the world's leading trading nation, remains, as The Economist aptly puts it, "the engine of the world economy."

The United States has unprecedented economic might, and might of all kinds must always be used for right. One responsibility of the United States of America as the world's leading economic power during this difficult time in the history of the world is the responsibility of continuing to support the world trading system that is served by the WTO. The pressures of protectionism and the politics of parochialism must not prevent Americans from seeing our true and enduring interest in the continued success of the WTO, and in the continued strengthening of the WTObased multilateral trading system. 
In particular, the WTO is an example to the world that a multilateral system for the peaceful settlement of international disputes can work. The world is much in need nowadays of such examples. Trade is not terrorism. Widgets are not warfare. Even so, we Americans are much in need nowadays of opportunities for reassuring the rest of the world that we seek the success of multilateral systems for international cooperation and for international dispute settlement. The WTO is one such opportunity we must seize in our continued efforts to provide that reassurance.

The American philosopher John Rawls, in the tradition of Mill, and in the spirit of Lecky, suggested "reasonableness" as a way of bringing people from different backgrounds and cultures together to address common concerns (see John Rawls, Political Liberalism (New York: Columbia University Press, 1993) 212-254; and John Rawls, The Law of Peoples (Cambridge, Massachusetts: Harvard University Press, 1999) 129-80).

He saw value in simply trying to work together. He saw potential in talking and listening and reasoning together. To be sure, not everyone will be persuaded by reason, and, thus, not every international dispute can be resolved by resort only to reason. Others are not always reasonable. Trust is not always attainable. But trust is always desirable. Trust is better than troops. Reason must always be our first resort. The abandonment of reason through the use of force must always be our last.

In urging "reasonableness," Rawls had great faith in particular in what he called "public reason." By this, he meant active participation by active citizens in a free and ongoing public debate. He meant a public deliberation leading to an act of decision-making in which all who participated would feel that they had an active part. From such a deliberative process would come, he believed, what we would call in the WTO a "consensus."

A "consensus" in the WTO is not unanimity. Article IX, paragraph 1, of the Marrakesh Agreement establishing the World Trade Organization provides that, with respect to decision-making, "The WTO shall continue the practice of decision-making by consensus followed under GATT 1947." Footnote 1 to this provision of the WTO treaty explains, "The body concerned shall be deemed to have decided by consensus on a matter submitted for its consideration, if no member, present at the meeting when the decision is taken, formally objects to the proposed decision."

Thus, a "consensus" in the WTO is an agreement to go along and to go forward and to go together as one - even in the absence of absolute unanimity. It is a decision that none question because it is a decision that none, in the end, feel compelled to oppose actively. It is a decision in which all are willing to join, because it is one in which all have played a part in making. A decision resulting from a WTO consensus is a decision resulting from an active exercise in the WTO equivalent of "public reason." By no means is a consensus ever easily achieved within the WTO on a contentious or controversial issue. But a consensus that is finally achieved within the WTO on such an issue is a consensus well worth the effort and well worth the having. In my view, the world desperately needs more such active international exercises in "public reason."

One nation may, at a certain moment in history, have the power to work its will on many other nations. In our fractious and fragmented world of nations, one nation may, at a certain moment, have the power to do as it wishes without listening to other nations, and without reasoning with them in a sincere effort to reach anything even resembling a consensus. But my reading of history reminds me that such moments in history can be fleeting, even for the most powerful of nations.

Far better to reason together. Far better for every nation, no matter how powerful it may happen to be at some passing historical moment, to have the patience to engage in "public reason" by reasoning with others and, especially, by listening to others. For the seven of us at the round table of the Appellate Body, for the 146 members of the WTO, for all the nations of the world in all that they must try to do together, this is the only way to reach a real consensus, and this is the only way to make continued and lasting progress in expanding the circle of humanity.

This article is taken from the lecture given by James Bacchus at the Institute of Advanced Legal Studies on 10 April 2003.

\section{James Bacchus}

The author is the Chairman of the Appellate Body of the World Trade Organization in Geneva, Switzerland. He is the youngest, longest serving and only North American member. Bacchus is a former Special Assistant to the United States Trade Representative in the Executive Office of the President. He is also a former member of the Congress of the United States (from Florida), and served two terms in the US House of Representatives before choosing not to seek re-election in 1994.

He was recently named to the law faculty as a professor of law at Vanderbilt University Law School. These are his personal views, and are not the views of his colleagues on the Appellate Body or the official views of the WTO.

(C) James Bacchus 